\author{
Селіхов С.В. \\ аспірант \\ кафедра менеджменту та логістики \\ Одеська національна академія харчових технологій \\ вул. Канатна, 112, м. Одеса, Україна, 65039 \\ E-mail: selkom@icloud.com
}

\title{
АНАЛІЗ НАПРЯМКІВ ІННОВАЦІЙНОГО РОЗВИТКУ ПІДПРИЄМСТВ ВИНОРОБНОї ГАЛУЗІ
}

У статті розглянуті заходи щодо впровадження інноваційних розробок на виноробних підприємствах Одеської області. Проведено порівняльний аналіз використання управлінських, технологічних та товарних інновацій на підприємствах виноробної галузі. проведено SWOT-аналізу означених підприємств, що дало змогу зробити висновки щодо подальшого стратегічного розвитку. Запропоновано заходи щодо підвищення ефективності діяльності підприємств. ний аналіз.

Ключові слова: стратегія, інноваційний розвиток, підприємства виноробної галузі, стратегіч-

This work is licensed under a Creative Commons Attribution 4.0 International License http://creativecommons.org/licenses/by/4.0/

Постановка проблеми та їі зв'язок з важливими науковими та практичними завданнями. Сучасний етап розвитку економіки України характеризується докорінною зміною умов функціонування підприємств, що обумовлюється підвищенням рівня мобільності зовнішніх чинників та посиленням їх впливу на внутрішнє середовище. Ефективна діяльність та подальший розвиток вітчизняних виноробних підприємств повинні базуватися на принципах стратегічного та інноваційного управління, яке має вирішувати задачі забезпечення конкурентоспроможності, докорінну перебудову системи управління, 3 метою підвищення іiі гнучкості та адаптивності до змін у зовнішньому середовищі, сприйнятливості до нововведень; максимальне використання інтелектуального потенціалу управлінського персоналу, техніки і технології; постійне впровадження заходів щодо самовдосконалювання та саморозвитку системи управління.

Україна має високий потенціал розвитку сільськогосподарської галузі. Площа чорнозему становить 27,8 га, що становить $8,7 \%$ від світових площ. Одним з перспективних напрямків розвитку сільськогосподарської галузі, є виноробство. Ефективне використання ресурсів дозволяе збільшити ВВП нашої країни, а також забезпечити діяльність українських виробників, забезпечити робочі місця, що є пріоритетним розвитком в період економічної кризи.

Аналіз останніх публікацій по проблемі. Проблеми стратегічного управління відображені в наукових працях закордонних та вітчизняних вчених: О. Віханського, І. Бланка, Р. Фатхудинова, А. Дж. Стрікленда, І. Ансоффа, Ф. Котлера та ін. Переважно їхні роботи пов'язані 3 управлінням великими багатопрофільними підприємствами. Існуючі наукові підходи носять загальний характер, що обмежує сферу їхнього застосування у зв'язку зі специфічними галузевими особливостями. Тому у даному досліджені виникла потреба у розгляді теоретичних і методичних питань, пов'язаних 3 впровадженням управлінських інновацій на підприємствах виноробної галузі. Актуальність та практична значущість цих питань зумовили вибір теми даного дослідження, його мету та завдання.

Формулювання цілей дослідження. Метою статті є дослідження стану використання інновацій (управлінських, технологічних, продуктових) та обгрунтування запропонованих заходів щодо підвищення ефективності діяльності підприємств виноробної галузі на основі SWOT- аналізу.

Виклад основних результатів та їх обгрунтування. Верховною Радою України у 2002 було прийнято Концепцію науково-технологічного та інноваційного розвитку України. Базовий закон у цій сфері «Про інноваційну діяльність». Закон визначає мету та принципи державної інноваційної політики. Головною метою державної інноваційної політики визнається створення соціально-економічних, організаційних і правових умов для ефективного відтворення, розвитку й використання науково-технічного потенціалу країни, забезпечення впровадження сучасних екологічних чистих, безпечних, ресурсозберігаючих технологій, виробництва та реалізації нових видів конкурентоспроможної продукції.[3]

Кліматично та географічне розташування України створює всі умови для виробництва унікальних терруарних вин. На території України виділено 15 макро- і 58 природно виноградарських микрозон в Одеській, Херсонській, Миколаївській, Закарпатській та Запорізькій областях. Однак на 48,7 тис. га україн - 
ських виноградників припадає лише 61 підприємство, що має лінії розливу, тобто близько 800 га насаджень на один винзавод. Площа виноградників в Україні станом на 1 січня минулого року дорівнює 48,7 тисячі гектарів, $з$ яких виноробами було вироблено 13,9 млн. дал виноматеріалів. Це приблизно 1\% від обсягів країн Свропи. При цьому близько 44,2 тис. га українських виноградників плодоносні, і в 2016-му дали 351,8 тис. тонн валового збору винограду. Серед позитивних змін, які відбуваються вже зараз, можна визначити зростання врожайності виноградних насаджень в останні 10 років - 3 30-40 ц / га до 80-90 ц / га. Ще одним позитивним трендом, є перші кроки по напрямку провідних підприємств і фермерських господарств на виробництво вин і виробництва органічної виноробної продукції. Так, критеріями Свросоюзу щодо географічного зазначення PDO (Protected Designation of origin, продукт, пов'язаний з його територією) відповідають 5 торгових марок ПТК «Шабо», ряд підприємств використовує торговельні марки 3 визначенням регіону виробництва продукції за критеріями, зазначеними в TSG (Traditional Specialies Guarantied).

Таблиця 1

Експорт імпорт вин в країнами світу у 2016 р.*

\begin{tabular}{|l|c|c|c|c|c|}
\hline \multicolumn{1}{|c|}{ Країна експортер } & $\begin{array}{c}\text { Обсяг } \\
\text { експорту, } \\
\text { млн.дол., США }\end{array}$ & $\begin{array}{c}\text { Частка } \\
\text { експорту, \% }\end{array}$ & $\begin{array}{c}\text { Країна } \\
\text { імпортер }\end{array}$ & $\begin{array}{c}\text { Обсяг } \\
\text { імпорту, } \\
\text { млн. дол., США }\end{array}$ & $\begin{array}{c}\text { Частка } \\
\text { імпорту,\% }\end{array}$ \\
\hline Російська Федерація & 26,4 & 69,1 & Італія & 16,8 & 29,8 \\
\hline Грузія & 3,3 & 8,6 & Франція & 10,9 & 19,3 \\
\hline Азербайджан & 1,3 & 3,4 & Грузія & 12,9 & 24,0 \\
\hline Німеччина & 1,3 & 3,4 & Молдова & 4,9 & 10,8 \\
\hline Китай & 0,7 & 1,8 & Німеччина & 8,4 & 5,6 \\
\hline Інші країни & 5,23 & 13,7 & Чилі & 8,2 & 10,5 \\
\hline
\end{tabular}

*сформовано автором за даними [7]

Всього експортовано виноградних вин в 2015 році на суму 38,2 млн. дол. США, імпортовано 56,4 млн. Дол. США. Всього в світі 9,5 - 10,0 млн. га площ виноградників. Щорічне виробництво винограду 60-70 млн.тонн, вина 280 млн. Г.Л. Світові лідери за обсягами виробництва вина: Італія до 45 млн. г.л., Франція до 44 млн. г.л., Іспанія до 40 млн. г.л. В Україні на 1 січня 2016 року, площа виноградників склала 48,7 тис.га. Основними виробниками виноробної продукції є торгові марки: «Таврія», «Інкерман» (виробництво на потужностях ДМК «Таврія»), ПрАТ «Одесавинпром» ТМ «Французький бульвар», «Золота балка» (КЗШВ «Столичний»), «Ореанда» («Одеський коньячний завод»), «Коктебель» («Одеський коньячний завод»), «Магарач» («Цюрупинське»), «Коблево», ПТК«Шабо», ТОВ «Тиса» («Ужгородський коньячний завод»), «Таїрове» («Нива»). Міжнародний сертифікат на виробництво органічної винограду i вина отримало фермерське господарство «Перлина струмка» (TM PetroV), Одеська обл. Існує три основних типи інноваційних стратегій розвитку національної економіки, галузевої економіки та окремо взятого підприємства:

- стратегія «перенесення» (переважне використання іноземного наукового-технічного потенціалу і впровадження розроблених за кордоном технологій у власне виробництво);

- стратегія «запозичування» (освоєння виробництва продукції, що вироблялалсь раніше у розвинених країнах із нарощуванням власного інженернотехнічного супроводу виробництва);

- стратегія «нарощування» (використання національного науково-технічного потенціалу, залу- чення іноземних науковців і фахівців ( імпорт робочої сили), залучення інноваційних капіталів.

Проведене дослідження дало змогу визначити основні типи інноваційної діяльності виноробних підприємств Одеської області, а саме: продуктові, технологічні та організаційні інновації. 3 точки зору діяльності підприємства в сфері продуктових інновацій автором виділено напрям зі створення і вирощування нових сортів винограду, купажування наявних сортів. Створення і виведення на ринок нових видів продукції таких, наприклад як крижане вино «ісе wine». Одним із прикладів продуктових інновацій $є$ використання для закупорювання продукції полімерних пробок, які замінюють дорогі пробки з натурального коркового дерева. У низькому ціновому сегменті, дана продуктова інновація виявилася економічно доцільною і успішною. Більшість підприємств виробників використовують полімерні пробки для закупорювання вина і шампанського. Слід зазначити, що деякі винороби скептично поставилися до полімерної пробці, яка обмежує доступ кисню до вина. Однак розробки в даному напрямку тривають, так наприклад фахівцями компанії «Вин Перфект» була розроблена спеціальна полімерна пробка 3 пластикової прокладкою покритої алюмінієм, яка дозволяє контролювати кількість повітря потрапив в пляшку. Також одним із прикладів продуктових інновацій $є$ вирішення проблеми відкритої відкоркованої пляшки. Рішення, запропоноване Грег Ламбрехт, в використанні приладу Goravin, який за допомогою голки протикає пробку i наповнює келих, після витягування голки 3 пробки, пробка заповнює простір, що утворився, закриваючи доступ до кисню. Після серії проведених дегустацій, 
експерти не змогли відрізнити знову відкрите вино від раніше відкритої пляшки вина і законсервованого методом Gorvin. Дане нововведення дозволяє дегустувати рідкісні сорти вин, не побоюючись за подальше зберігання.

В Одеській області лідером впровадження товарних інновацій є ПТК «Шабо». Підприємство займається виробництвом продукції з повним циклом від вирощування винограду до розливу в тару. На підприємстві функціонує департаментная організаційна структура управління. Площа виноградників складає 1400 га, а також 40 га в Грузії. Основні сорти винограду: Каберне-Совіньйон, Мерло, Піно-Нуар, Сапераві, Шардоне, Совіньон-Блан і інші. ПТК «Шабо» має в своєму розпорядженні цех з переробці винограду площею 1300 кв. метрів, в сезон переробляється близько 12000 тонн винограду, червоних і білих сортів. Всі процеси повністю автоматизовані, сучасне обладнання забезпечує постійний температурний контроль і ефективний режим переробки сировини. На підприємстві розташований цех 3 виробниц- тва та зберігання елітних вин. 32005 р., ПТК «Шабо» виробляє коньяки і бренді, а з 2013 року виноградну горілку. Вино сховище ПТК «Шабо» одне з найбільших в Україні і займає 10000 кв. метрів. Сучасна лабораторія здійснює контроль якості на кожному етапі виробництва. Відділення для бутилювання продукції складається 39 сучасних ліній розливу, потужністю 50 млн. пляшок на рік. Всього під торговою маркою «Шабо» випускається близько 80 найменувань продукції. Обсяг випуску 42 млн. Пляшок на рік, з них 2/3 коньяки і бренді. Кількість працюючих 640 чоловік, в сезон залучаються тимчасові робітники, близько 300 осіб. Основна продукція - коньяки і бренді, частка в загальному обсязі виробництва 65-70 \%. Підприємство як нововведення використовує процес безвідходного виробництва 3 допомогою сучасної котельні яка працює на відходах виробництва в тому числі на залишках лози, висушені мезги.

Для визначення напрямку інноваційного розвитку ПТК «Шабо було проведено SWOT аналіз (табл. 2).

Таблиця 2

SWOT аналіз ПТК «Шабо»*

\begin{tabular}{|c|c|c|c|}
\hline \multicolumn{2}{|r|}{ Сильні сторони } & \multicolumn{2}{|r|}{ Слабкі сторони } \\
\hline Рейтинг & Параметр & Рейтинг & Параметр \\
\hline 1 & Популярність торгової марки & 1 & Слабке просування новинок \\
\hline 2 & Наявність нагород & 2 & Відсутність фірмових магазинів \\
\hline 3 & Якість продукції & 3 & Слабка представленість в торгових мережах \\
\hline 4 & Сучасні технології & 4 & Відсутність реклами в преміум сегменті \\
\hline 5 & Наявність власної сировинної бази & & \\
\hline 6 & Сертифікація системи менеджменту & & \\
\hline 7 & Залученість персоналу & & \\
\hline \multicolumn{2}{|r|}{ Можливості } & \multicolumn{2}{|r|}{ Загрози } \\
\hline Рейтинг & & Рейтинг & \\
\hline 1 & $\begin{array}{l}\text { Створення мережі фірмової торгівлі через } \\
\text { франчайзинг }\end{array}$ & 1 & Конкуренція імпортної продукції \\
\hline 2 & $\begin{array}{l}\text { Виробництво упаковки як зворотна вер- } \\
\text { тикальна інтеграція }\end{array}$ & 2 & Підвищення цін на упаковку \\
\hline 3 & Збільшення виробничих потужностей & 3 & Зміна переваг споживачів \\
\hline
\end{tabular}

За результатами проведеного аналізу, пропонується використовувати стратегію зворотної вертикальної інтеграції, яка реалізується шляхом будівництва цеху тари і упаковки та будівництва додаткових виробничих потужностей. Також доцільно в просуванні продукції для цільової аудиторії в преміум сегменті робити акцент на наявність у підприємства міжнародних нагород.

ЗАТ «Одесавинпром». Підприємство є лідером з виробництва вина в Одеській області, сировинна база 2500 га виноградників, частка ринку $8 \%$ від загальної кількості виробленого в Україні. Основні сорти винограду Шардоне, Ркацителі, Піно, Рислінг та інші. Сучасне обладнання знаходиться в с. Розівка i с. Долинка Одеської області. У складі підприємства 2 заводи первинного виноробства, 3 цеху виробництва ігристих вин, 2 цехи витримки виноматеріалу в дубовій тарі, 6 ліній розливу. На виробничих потужностях підприємства проводиться розлив продукції торгових марок «Інкерман», «Баядера», «Олімп», «Маренго». Річний випуск вина - 800 тис. дал, шампанського - 600 тис. дал. Під торговою маркою «Французький бульвар» випускається близько $30 \%$ продукції, решта виробництво переробка давальницької сировини та розлив для інших підприємств на умовах аутсорсингу. На підприємстві діє департаментная організаційна структура управління, за кожним департаменту ведеться окремий управлінський облік. ЗАТ «Одесавинпром» управляється комплексною автоматизованою системою управління підприємством, шляхом впровадження ERP-системи «ITПідприємство» (проект був початий на початку 2002 року). В єдиній системі управління працюють: цеху обробки і розливу, відділи маркетингу, постачання, збуту, бухгалтерія, ВЕО, склади. В рамках проекту реалізована прогресивна концепція управління якістю, що дозволяє отримати звід показників, що впливають на якість продукції на кожному етапі обробки. 
В системі постійно відображається поточний стан виробництва: на якому складі, обладнанні, етапі обробки знаходиться сировину або напівфабрикат і 3 якої партії, від якого постачальника і в якій кількості, 3 якими лабораторними характеристиками. Для будьякої партії готової продукції можна отримати розгорнуту історію приготування даної партії - від вхідного виноматеріалу, по всіх переділах, з усіма характеристиками якості на кожному етапі, з усіма обробними матеріалами, використаними на кожному етапі. А вибравши будь-яку вхідну партію виноматеріалу, можна отримати таку ж історію обробки цього вина аж до партії готової продукції, в яку потрапив даний матеріал. Автоматично формуються технологічні журнали і сертифікати якості. Введено в промислову експлуатацію підсистеми технічної підготовки виробництва, управління виробництвом, управління матеріальними ресурсами, техніко-економічного планування, обліку матеріальних цінностей, обліку витрат на виробництво, фінансового обліку, управління якістю, договірного обліку, управління цінами, бухгалтерського та податкового обліку. На підприємстві впроваджено потужний механізм управління якістю виробництва з урахуванням специфіки виноробства, що дозволяє простежити проходження виноматеріалів на всіх етапах обробки, з фіксацією показників від придбання до передачі на розлив і реалізації. Складність інноваційного проекту полягала у відсутності жорсткого регламенту технології приготування вина. Сам процес може включати в себе від 2 до 12 переділів, що залежить від лабораторних показників отриманого виноматеріалу і характеристик напівфабрикату, знятих після кожного переділу.

Особливістю впровадження управлінських інновацій в ЗАТ «Одесавинпром» були роботи: зі створення наскрізного планування та обліку виготовлення продукції на всіх етапах виробництва. На кожному етапі (транспортування, приймання, ассамбляж, обклеювання, фільтрація та обробка теплом / холодом) до самого розливу забезпечений облік витрат та узгодження 3 нормативами; автоматизований облік склотари, розрахунок втрат за нормами і понад норму, система обліку поворотної тари, операції з давальницькою сировиною; автоматичний розрахунок акцизного збору (різні ставки по групах продукції), формування звітних форм для щоденної сплати податку; розроблена програма контролю за цінами відвантаження, гнучка шкала знижок, контролю заборгованості покупців з урахуванням відстрочки платежу; розроблена система обліку по партіях готової продукції з урахуванням дати випуску і номери купажу; автоматичний друк сертифікатів якості на кожну партію готової продукції до відвантажувальних документів планування потреб матеріалів і оперативне лімітування, облік по партіях виробництва по всіх переділах. Оперативне відображення поточного стану виробництва: на якому складо-місці, на якому обладнанні, на якому етапі обробки знаходиться сировину або напівфабрикат з якої партії, від якого постачальника i в якій кількості, з якими лабораторними характеристиками. При необхідності можна переглянути весь ланцюг руху будь-якого етапу, автоматичний розрахунок витрат на кожному етапі та розрахунок збільшення обсягу при обробці допоміжними матеріалами, формування специфічних документів, 3 відображенням розрахункових показників, автоматичне ведення журналів паспортів якості на обробку по всіх переділах, облік характеристик на кожному переділі, реєстрація характеристик якості і статистичний аналіз характеристик в динаміці, простежуваності для будьякої партії готової продукції історії приготування, починаючи від вхідного виноматеріалу, по всіх переділах, з усіма характеристиками якості на кожному етапі, з усіма обробними матеріалами, використаними на кожному етапі, для будь-якої вхідної партії виноматеріалу історії обробки цього вина по всіх переділах до партії готової продукції, в яку потрапив даний матеріал, контроль якості вхідної сировини в розрізі постачальників, порівняльний аналіз постачальників, графікових планування виробництв, облік виконання оперативних виробничих планів; варіантне калькулювання нормативної собівартості, калькулювання фактичної собівартості продукції, аналіз динаміки цін і рентабельності продукції за періодами. Дані види робіт дозволили сформувати цілісну структуру інноваційної політики на підприємстві. Яка забезпечує підприємству конкурентну перевагу на ринку, у вигляді нових продуктів, технологій і методів управління.

Таблиця 3

SWOT аналіз 3АT «Одесавинпром»*

\begin{tabular}{|c|l|c|l|}
\hline \multicolumn{2}{|c|}{ Сильні сторони } & \multicolumn{2}{c|}{ Слабкі сторони } \\
\hline Рейтинг & Параметр & Рейтинг & Параметр \\
\hline 1 & Популярність торгової марки & 1 & Відсутність новинок продукції \\
\hline 2 & Лояльність споживачів & 2 & Відсутність ре-дизайну упаковок \\
\hline 3 & Доступна ціна продукції & 3 & Відсутність РR, особи бренду \\
\hline 4 & Сучасні виробничі потужності & 4 & Відсутність преміум продукції \\
\hline 5 & Високий рівень технологій виробництва & 5 & Відсутність подарункової упаковки \\
\hline 6 & Наявність власної сировинної бази & 6 & Відсутність плодово-ягідних вин \\
\hline 7 & Використання всіх каналів збуту & & \\
\hline
\end{tabular}


Продовження табл. 3

\begin{tabular}{|c|l|c|l|}
\hline \multicolumn{2}{|c|}{ Можливості } & \multicolumn{2}{|c|}{ Загрози } \\
\hline Рейтинг & \multicolumn{1}{|c|}{} & Рейтинг & \multicolumn{1}{|c|}{} \\
\hline 1 & Створення преміум товару & 1 & Вибір споживачами нової продукції \\
\hline 2 & Виробництво плодово-ягідних вин & 2 & $\begin{array}{l}\text { Створення замовниками власних ліній роз- } \\
\text { ливу }\end{array}$ \\
\hline 3 & Вихід на нові ринки збуту & 3 & $\begin{array}{l}\text { Зростання вартості сировини випереджаюче } \\
\text { зростання цін на продукцію }\end{array}$ \\
\hline 4 & $\begin{array}{l}\text { Проведення РR компанії, створення осо- } \\
\text { би бренду }\end{array}$ & 4 & $\begin{array}{l}\text { Вхід на ринок нових компаній виробників } \\
\text { вина }\end{array}$ \\
\hline 5 & Створення колекційного набору & 5 & Зміна переваг покупців в преміум сегменті \\
\hline 6 & $\begin{array}{l}\text { Виробництво скляної тари, як зворотна } \\
\text { вертикальна інтеграція }\end{array}$ & 6 & \\
\hline
\end{tabular}

За результатами проведеного аналізу пропонується для просування продукції на ринку, залучення відомої особистості (актор, артист) - як обличчя бренду. Використання в рекламі продукції відомої і популярної особистості дозволить збільшити продажі в преміум сегменті ринку. Також рекомендується розробка колекційного подарункового набору в який підприємство може включити широкий асортимент наявної продукції. Одним з найважливіших напрямків розвитку, є будівництво цеху з виробництва плодовоягідних вин.

Слід зазначити наявність виноробних підприємств в Одеській області що не впроваджують інновацій і не використовують сучасні розробки в області технологій, організації виробництва, а також продук- тових новинок. Згідно з проведеним аналізом, таким підприємством є ПрАТ «Одеський завод шампанських вин». Завод побудований в 1898 році і знаходиться в м Одеса, Французький бульвар, 10 і є найстарішим виноробним підприємством Одеської області. Виробнича потужність заводу - 15 млн. Пляшок на рік. Основний асортимент: шампанське і тихі вина. Виробництво функціонує на давальницькій сировині, в зв'язку відсутністю сировинної бази. Основна продукція - шампанське випускається під торговою маркою «Одеса». Підприємство має лінійну організаційну структуру. У зв'язку з частими змінами власника, підприємство не має стратегічного плану розвитку, відсутня маркетингова стратегія.

Таблиця 4

SWOT аналіз ПрАT «Одеський завод шампанських вин»*

\begin{tabular}{|c|c|c|c|}
\hline \multicolumn{2}{|r|}{ Сильні сторони } & \multicolumn{2}{|r|}{ Слабкі сторони } \\
\hline Рейтинг & Параметр & Рейтинг & Параметр \\
\hline 1 & Наявність ТМ "Одеса" & 1 & Відсутність власної сировинної бази \\
\hline 2 & Мерчандайзинг в торгових мережах & 2 & Стара упаковка і дизайн \\
\hline 3 & Доступна ціна продукції & 3 & $\begin{array}{l}\text { Відсутність всього асортименту в торгових } \\
\text { мережах }\end{array}$ \\
\hline 4 & Популярність торгової марки "Одеса" & 4 & Відсутність подарункової упаковки \\
\hline 5 & Сучасне виробниче обладнання & 5 & Відсутність преміум товару \\
\hline 6 & & 6 & Відсутність реклами продукції \\
\hline 7 & & 7 & Часта зміна власників і менеджменту \\
\hline 8 & & 8 & Лінійна ОСУ \\
\hline 9 & & 9 & Низька залученість персоналу \\
\hline \multicolumn{2}{|r|}{ Можливості } & \multicolumn{2}{|r|}{ Загрози } \\
\hline Рейтинг & & Рейтинг & \\
\hline 1 & $\begin{array}{l}\text { Просування повного асортименту проду- } \\
\text { кції на ринку }\end{array}$ & 1 & Підвищення цін на давальницьку сировину \\
\hline 2 & Створення преміум товару & 2 & Підвищення цін на тару і упаковку \\
\hline 3 & $\begin{array}{l}\text { Створення дегустаційного залу та музею } \\
\text { вина }\end{array}$ & 3 & Зниження продуктивності праці \\
\hline 4 & $\begin{array}{l}\text { Інформаційний буклет з повним асорти- } \\
\text { ментом }\end{array}$ & 4 & Активність конкурентів на ринку \\
\hline 5 & $\begin{array}{l}\text { Включення відвідування заводу в екскур- } \\
\text { сійну програму }\end{array}$ & 5 & Втрата патенту на ТМ "Одеса" \\
\hline 6 & Участь в міжнародних виставках & 6 & Зниження лояльності споживачів \\
\hline
\end{tabular}


Висновки та перспективи подальших досліджень. На основі проведено дослідження можна зробити такі висновки:

1. Доведено, що особливістю впровадження управлінських інновацій на ЗАТ «Одесавинпром» $\epsilon$ створення наскрізного планування та облік виробництва продукції на всіх етапах технологічного ціклу.

2. Визначено, що дані види робіт дозволяють сформувати цілісну структуру інноваційної політики на підприємстві, яка забезпечує конкурентну перевагу на ринку, у вигляді нових продуктів, технологій та методів управління.
3. За результатами проведеного аналізу запропоновано, задля просування продукції на ринок, залучення відомої особистості, як обличчя бренду. Використання в рекламі продукції відомої і популярної особистості дозволить збільшити продажі в преміям-сегменті.

4. Запропоновано розробку колекційного подарункового набору в який підприємство може включити широкий асортимент наявної продукції.

5. Визначено, що одним з головних напрямів розвитку підприємств, $є$ будівництво цеху з виробництва плодово-ягідних вин.

\section{Література}

1. Петров А.Н. Стратегический менеджмент / под ред. А.Н. Петрова. - Спб.: Питер, 2008. - 496 с.

2. Виханский О.С. Менеджмент: [учебник] / О.С.Виханский. - [3-е изд.]. - М .: Экономисть, 2003. $528 \mathrm{c}$.

3. Томпсон-мл. Артур А. Стратегический менеджмент: концепции и ситуации для анализа / Артур А. Томпсон-мл.; пер. с англ. - [12-е изд.]. - М.: Издательский дом «Вильямс», 2009. - 928 с.

4. Фатхутдинов Р.А. Инновационный менеджмент: [учебник для вузов] / Р.А.Фатхутдинов. - [6-е изд.]. - СПб.: Питер, 2008. - 448 с.

5. Державний комітет статистики України [Електронний ресурс]: офіц. сайт. - Режим доступу : http://www.ukrstat.gov.ua.

6. Барышева А.В. Инновации: [учеб. пособие]. - М.: Издательско-торговая корпорация «Дашков и Ko.», 2007. - 382c.

7. Инновационный менеджмент: [учебник для вузов] / [Абрамешин А.Е., Воронина Т.П., Молчанова О.П., Тихонова Е.А., Шленов Ю.В.] ; под ред. О.П. Молчановой. - М.: Вита-Пресс, 2001. - 272 с.

8. Max Mckeown The Innovation Book: How to Manage Ideas and Execution for Outstanding Results, Pearson UK, 2014, $296 \mathrm{p}$.

9. Kelly, K. (2016). The Inevitable pp. 1-336. New York: Penguin Group.

10. Clayton M. Christensen, Michael E. Raynor The Innovator's Solution: Creating and Sustaining Successful Growth, Harvard Business School Press, 2003 - p. 304

11. Савенко I.І. Перспективні напрями інноваційної діяльності зернозберігаючих підприємств (Теоретико-правовий та методологічний аспекти): [монографія ] / I.І. Савенко. - Одеса: Поліграф, 2009. - 200 с.

Стаття надійшла 10.10 .2017

Стаття прийнята до друку 24.10.2017

Доступно в мережі Internet 30.12.2017

\section{Селихов С.В.} аспирант

кафедра менеджмента и логистики

Одесская национальная академия пищевых технологий ул. Канатная, 112, г. Одесса, Украина, 65039

E-mail: selkom@icloud.com

\section{АНАЛІЗ НАПРЯМКІВ ІННОВАЦІЙНОГО РОЗВИТКУ ПІДПРИЄМСТВ ВИНОРОБНОї ГАЛУЗІ}

В статье рассмотрены мероприятия по внедрению инновационных разработок в винодельческих предприятиях Одесской области. Проведен сравнительный анализ использования управленческих, технологических и товарных инноваций на предприятиях винодельческой отрасли. Проведен SWOT-анализ указанных предприятий, что позволило сделать выводы относительно дальнейшего стратегического развития. Предложены меры по повышению эфффективности деятельности предприятий.

Современный этап развития экономики Украины характеризуется коренным изменением условий функционирования предприятий, которое обусловливается повышением уровня мобильности 
внешних факторов и усилением их влияния на внутреннюю среду. Эффективная деятельность и последующее развитие украинских винодельческих предприятий должны базироваться на принципах стратегического и инновационного управления.

Существующие научные подходы носят общий характер, который ограничивает область их применения в связи со специфическими отраслевыми особенностями. Поэтому в данном исследованные возникла потребность в рассмотрении теоретических и методических вопросов, связанных с внедрением управленческих инноваций, на предприятиях винодельческой отрасли. Актуальность и практическая значимость этих вопросов обусловили выбор темы данного исследования, его цель и задание. Целью статьи является исследование состояния использования инноваций (управленческих, технологических, продуктовых) и обоснования предложенных мероприятий по повышению эффективности деятельности предприятий винодельной отрасли на основе SWOT- анализа.

На основе проведенного исследования можно сделать такие выводы: 1. Доказано, что особенностью внедрения управленческих инноваций на ЗАО «Одесавинпром», является создание сквозного планирования и учет производства продукции на всех этапах технологического цикла. 2. Определено, что данные виды работ позволяют сформировать целостную структуру инновационной политики на предприятии, которая обеспечивает конкурентное преимущество на рынке, в виде новых продуктов, технологий и методов управления. 3. По результатами проведенного анализа предлагается, для продвижения продукции на рынок, привлечение известной личности, как лицо бренда. Привлечение к рекламе продукции известной и популярной личности позволит увеличить продажи в премиямсегменти. 4. Предложена разработка коллекционного подарочного набора в которое предприятие может включить широкий ассортимент имеющейся продукции. 5. Определено, что одним из главных направлений развития предприятий, является строительство цеха для производства плодовоягодных вин.

Ключевые слова: стратегия, инновационное развитие, предприятия винодельческой отрасли, стратегический анализ.

Selikhov S.

Postgraduate Department of Management and Logistics

Odessa National Academy of Food Technologies

Kanatna str., 112, Odesa, Ukraine, 65039

E-mail: selkom@icloud.com

\section{ANALYSIS OF DIRECTIONS OF INNOVATIVE DEVELOPMENT OF VINEYARD COMPANIES}

The article deals with measures to introduce innovations at wineries in the Odessa region. A comparative analysis of the use of innovative potential in managerial, technological and commodity innovations at enterprises of PTB "Shabo", CJSC "Odessa Champagne Wine Factory", CJSC "Odessavinprom». A comprehensive analysis of the strategic development of enterprises using SWOTanalysis is done. Measures are proposed to improve the efficiency of enterprises. The innovative activity of the enterprise ensures a qualitative increase in the efficiency of processes and products. Enterprises innovate to ensure the competitiveness of their products in the wine market. The object of research is the wine-making enterprises of the Odessa region. The subject of the study is the economic and innovative activity of wineries. On the basis of the data obtained, measures were proposed to improve the competitiveness of the winemaking enterprises of the Odessa region. The strategy of development and improvement of the product, organizational and managerial innovations have been defined. Existing scientific approaches carry general character which limits their application domain in connection with specific branch features. Therefore, in the given investigation there was a requirement in consideration of theoretical and methodical questions, related to introduction of administrative innovations, on the enterprises of vine making industry. Urgency and practical meaningfulness of these questions stipulated the choice of the theme of this research, its purpose and task.

The modern stage of the development of the economy of Ukraine is characterized by the native change of operating of enterprises, which is stipulated by the increase of level of mobility of external factors and strengthening of their influence on the internal environmental, conditions. The effective activity and subsequent development of the Ukrainian vine making enterprises must be based on principles of strategic and innovative management. The purpose of the article is investigation of the state of the use of innovations (administrative, technological, food) and substantiation of the offered measures on the increase of efficiency of of enterprises activities of vine making industry on the basis of SWOT-analysis. On the basis of the 
conducted research it is possible to do such conclusions: 1. It is well-proven that the peculiarity of introduction of administrative innovations on joint-stock COMPANY of "Odesavinprom", is creation of the through planning and account of production of goods at all stages of the technological cycle. 2. It has been determined, that these types of works allow to form the integral structure of innovative policy at an enterprise, which provides a competitive advantage in the market, as new products, technologies and management methods. 3. As a result of the conducted analysis it has been offered, for promotion of products to the market, to bring in the famous personality, as the face of the brand. The use it has been offered of the famous and popular personality will allow to increase sales in bonuses by segments. 4 . The development of the collection gift set has been offered in which an enterprise can include the wide range of the available products. 5. It has been determined, that one of main directions of development of enterprises, is building the of workshop for the production of fruit and berry wines.

Key words: strategy, innovative development, wine industry enterprises, strategic analysis.

\section{References}

1. Petrov, A. N. (2008). Strategicheskiy menedzhment. Sankt Peterburg: Piter.

2. Vihanskiy, O. S. (2003). Menedzhment. Ekonomist'.

3. Tompson, A. A., Ml. (2009). Strategicheskiy menedzhment: kontseptsii i situatsii dlya analiza. Izdatelskiy dom «Vilyams».

4. Fathutdinov, R. A. (2008). Innovatsionnyiy menedzhment. Sankt Peterburg: Piter.

5. Derzhavnyi komitet statystyky Ukrainy. (2017). Retrieved from http://www.ukrstat.gov.ua.

6. Baryisheva, A. V. (2007). Innovatsii. Izdatelsko-torgovaya korporatsiya «Dashkov i Ko.».

7. Abrameshin, A. E., Voronina, T. P., Molchanova, O. P., Tihonova, E. A., \& Shlenov, Yu. V. (2001). Innovatsionnyiy menedzhment (O. P. Molchanova, Ed.). Vita-Press.

8. Mckeown, M. (2014). The Innovation Book: How to Manage Ideas and Execution for Outstanding Results. Pearson UK.

9. Kelly, K. (2016). The Inevitable. New York: Penguin Group.

10. Christensen, C. M., \& Raynor, M. E. (2003). The Innovator's Solution: Creating and Sustaining Successful Growth. Harvard Business School Press.

11. Savenko, I. I. (2009). Perspektyvni napriamy innovatsiinoi diialnosti zernozberihaiuchykh pidpryiemstv (Teoretyko-pravovyi ta metodolohichnyi aspekty). Odesa: Polihraf.

Received 10 October 2017

Approved 24 October 2017

Available in Internet 30.12.2017 